a difficult problem. This, it should be noted, is an isolated cognitive defect.

Few qualified doctors find the concept of acquired dyslexia, as for example the result of a cerebral vascular accident, difficult to accept, but strangely an inherited defect causing difficulty in learning to read in an otherwise normal child appears to be almost unbelievable. Were this not the case the term dyslexia would not be held in such suspicion and the powerful negating control that many educational psychologists hold over the whole problem of reading difficulties would never have eventuated.

One must sadly come to the conclusion that many doctors have abrogated their responsibilities for this important aspect of the school medical service. This has led to greater hardships for this group of children, who with their parents are in an impossible position to conduct their own defence. This is the chief cause for the shortage of specialised remedial teachers of which you make mention, whereas many other countries which recognise the true nature of the problem have no such deficit. For a more balanced view of the whole subject of the problem of children who cannot read I recommend a small book by MacDonald Critchley. ${ }^{1}$

It is, of course, recognised that this group of children with a neurological defect are suffering from only one of a number of causes of reading difficulties. They are, however, quite separate from the continuum usually recognised by the educational psychologists, which range from intellectual inadequacy at one end of the scale to neurosis at the other. They are nevertheless all too often incorporated into this, and as a result spend their secondary school careers in the general remedial section undergoing the usual group therapy. It is generally recognised by experts that they respond poorly to this and need much greater specialised teaching. ${ }^{2}$

They need, and are worthy of, special consideration, and as a working rule it is most misleading to qualify the degree of their disability as "particularly likely to express the behaviour-poor reading -in an adverse environment (for example, a large family or a poor school)." Most of them come from good caring and loving homes with two or three children, and it has not been my experience that any school shows particular poorness by demonstrating a greater number than others.

\section{Seething, Norfolk}

R D HARLAND

${ }^{1}$ Critchley, M, The Dyslexic Child, 2nd edn. London, Heinemann, 1970.

Department of Education and Science, Children with Specific Reading Difficulties, Report of the Advisory
Committee on Handicapped Children, p 4, para 15. Committee on Handicap
London, HMSO, 1972.

SIR,-With regard to your leading article (1 July, p 3), it should also be mentioned that those who study the physiology of education will mostly agree that a dedicated mother or other adult will prevent all chance of future reading difficulty if she arouses a very early interest by the infant in all aspects of wordstalking, reading, singing, drawing, writing, etc. ${ }^{1-3}$ In support for this early start it is obviously very desirable that all television programmes for children should illustrate some enjoyable aspects of all the language skills. The current failure of our TV children's programmes to help adequately in this way is, I think, quite deplorable and positively damaging to our national standards of education.

Oxford W RITCHIE RUSSELL

in common.

${ }^{1}$ Brierley, J, Growing and Learning. London, Ward Lock Educational, 1978.

2 Ibuka, M, Kindergarten is Too Late. London, Souvenir Press, 1977.

Russell, W R, Explaining the Brain. London, Oxford University Press, 1975.

\section{Hypostatic ulceration and male sex} chromosomal anomalies

SIR,-Dr R Howell (8 July, p 95) recently reported six cases of Klinefelter's syndrome suffering from ulceration of legs and collected from the literature 14 other cases of the same disorder. In this hospital we have, among 343 male mentally handicapped patients, the following sex chromosomal abnormalities: two with Klinefelter's syndrome, one with XXXXY syndrome, ${ }^{1}$ and another with XXYY syndrome. ${ }^{2}$ In 1968 we admitted a patient for assessment who had an XXXY/XXY sex chromosomal anomaly. All these patients suffer from varicose veins of various degrees and two (one with XXXXY and one with XXYY syndrome) from hypostatic ulceration of the legs.

As we have observed hypostatic ulceration in other clinical conditions and younger patients-for example, Prader-Willi syndrome $^{3}$ at 12 years of age-we are planning to investigate all the hospital population for hypostatic ulceration and varicose veins and we would be grateful for any relevant observations on this subject from workers in mental handicap and, for comparison, from workers with the normal population.

Purdown Hospital,

J JANCAR Stapleto 1 Jancar, J, Proceedings of the International Copenhagen
Congress for SSMR, $1964, \mathrm{vol} 1, \mathrm{p} 179$.
3 Jancar, J, Lancet, $1968,2,970$.
Jancar, J, fournal of Mental Deficiency Research, 1971,
15, 20.

SIR,-The article by Dr R Howell (8 July, $\mathrm{p}$ 95) provides evidence that chronic leg ulcers appear more often than expected in men with Klinefelter's syndrome. Dr Howell suggests that this chromosomal anomaly should be considered in men presenting with hypostatic ulceration.

We wish to draw attention to the fact that not only supernumerary $\mathrm{X}$ chromosomes in men but also additional $\mathrm{Y}$ chromosomes seem to have this effect. Court Brown et $a l^{1}$ found varicose ulcerations in two YY men in a series of 15 . We have systematically examined 24 men with double $\mathrm{Y}$ chromosomes, cared for in mental hospitals, with respect to the tendency to varicose veins. ${ }^{2}$ We recognised two grades, a severe and a milder. Subjects were assigned to the severe grade who, in addition to varicose veins, had complications in the form of attacks of thrombophlebitis or leg ulcers, either currently or in the medical history. Such a condition of severe varices with complications was present in five of our index cases $(21 \%)$. By comparison with the prevalence figures given in the literature we considered it justified to assert that our figure shows that the chromosomal constitution $47, \mathrm{XYY}$ carries with it an increased risk of varicose veins and hypostatic ulceration.

It is interesting that the two gonosomal
University of Göteborg,

Psychiatric Research Centre,

St Jörgen's Hospital,

Sweden.

${ }^{1}$ Brown, W M C, Price, W $\mathrm{H}$, and Jacobs, P A, British Medical fournal, 1968, 2, 325.

$Y$-chromosomes. Gröteborg, Akademiförlaget, 1975.

\section{Depot fluphenazine and tardive dyskinesia}

SIR,-The view expressed in Any Questions? (8 July, p 114) that the risk of causing longterm dyskinesia with depot fluphenazine is small is probably optimistic. Although different workers have described greatly differing figures for the incidence of tardive dyskinesia (TD) in different studies, their criteria for diagnosis must have differed, and recent investigations suggest a high incidence of the condition in patients who have received neuroleptic drugs for many years. For instance Bell and Smith, ${ }^{1}$ looking at the population in nine mental hospitals in Illinois and rating signs of all severity, found that $40 \%$ of patients exhibited probable evidence of TD and $26 \%$ showed undoubted signs. Most of these patients were on oral neuroleptics, but there is no reason to suppose that patients receiving fluphenazine by injection would be less likely to develop dyskinesia. Not only do they have less chance to be non-adherers to a treatment schedule, but the injection bypasses the vagaries of absorption of oral preparations. ${ }^{2}$

In this area we have nearly 400 patients on depot fluphenazine and fluphenthixol and since 197363 of them have developed TD, though it is fortunately mild in the majority. All had had other neuroleptics before. Nevertheless, depot injections have allowed thousands of people to lead reasonably normal lives outside hospital and it is surely better to have involuntary movements of the lower face and tongue than to suffer the disturbing perceptions of uncontrolled schizophrenia; if we psychiatrists would use neuroleptics in the smallest effective therapeutic dose (half my patients on fluphenazine need $12.5 \mathrm{mg}$ monthly) and eschew the use of the routine anticholinergic drugs the next generation of schizophrenics might have less trouble with TD than the present.

Alan C Gibson

St Ann's Hospital, ${ }^{1}$ Bell, R C H, and Smith, R C, fournal of Clinical
Psychiatry, $1978,39,39$ and 46.
${ }^{2}$ Adamson, L, et al, Diseases of the Nervous System, 1973, 34, 181 .

\section{Prostaglandin $F_{2}$ and tumours of the} female genital tract

SIR,-Williams et $a l^{1}$ first reported elevated levels of prostaglandins (PG) in tumour tissues and in the plasma of patients with medullary carcinoma of the thyroid. Subsequently, raised blood $\mathrm{PGE}_{2}$ and $\mathrm{PGF}_{2 \alpha}$ levels have been reported in association with a variety of human tumours, including phaeochromocytoma, carcinoid tumours, rectal carcinoma, Kaposi's sarcoma, neuroblastoma, bronchial carcinoma, islet cell tumours, and carcinoma of the breast. 